\title{
Effect of Dehydration Conditions on the Chemical, Physical, and Rehydration Properties of Instant Whole Bean (Phaseolus vulgaris L. var. Azufrado)
}

\author{
Juan Alberto Resendiz Vazquez, ${ }^{1}$ José Armando Ulloa, ${ }^{1,2}$ \\ Petra Rosas Ulloa, ${ }^{2}$ and José Carmen Ramírez Ramírez \\ ${ }^{1}$ Unidad Académica de Agricultura, Universidad Autónoma de Nayarit, Carretera Tepic-Puerto Vallarta, 63180 Xalisco, NAY, Mexico \\ ${ }^{2}$ Centro de Tecnología de Alimentos, Universidad Autónoma de Nayarit, Ciudad de la Cultura Amado Nervo, 63155 Tepic, NAY, Mexico \\ ${ }^{3}$ Unidad Académica de Medicina Veterinaria y Zootecnia, Universidad Autónoma de Nayarit, Carretera a Chapalilla, 63700 \\ Compostela, NAY, Mexico
}

Correspondence should be addressed to José Armando Ulloa; arulloa5@gmail.com

Received 15 December 2014; Accepted 28 April 2015

Academic Editor: Silvina Drago

Copyright (C) 2015 Juan Alberto Resendiz Vazquez et al. This is an open access article distributed under the Creative Commons Attribution License, which permits unrestricted use, distribution, and reproduction in any medium, provided the original work is properly cited.

\begin{abstract}
The purpose of this study was to evaluate the effect of dehydration conditions on the chemical, physical, and rehydration properties of instant whole beans (Phaseolus vulgaris L. var. Azufrado) using a $2^{2}$ factorial design (air temperature: $25^{\circ} \mathrm{C}$ and $30^{\circ} \mathrm{C}$, air velocity: $0.5 \mathrm{~m} / \mathrm{s}$ and $1.0 \mathrm{~m} / \mathrm{s}$ ). To determine the kinetic parameters, the rehydration data were fitted to three models: Peleg's, First Order, and Sigmoid. The protein, fat, and ash contents of the beans were not significantly affected $(P>0.05)$ by the dehydration conditions. Of the 11 physical properties of the instant whole beans, only water activity and splitting were significantly affected by dehydration conditions $(P<0.05)$, with a range from 0.58 to 0.67 and from $2.90 \%$ to $5.87 \%$, respectively. Of the three models tested, the First Order model gave the best fit for rehydration, with no significant differences $(P>0.05)$ between the observed and predicted equilibrium moisture contents of the instant whole beans. Regarding the rehydration kinetics for the instant whole beans, the activation energy values ranged from $23.56 \mathrm{~kJ} / \mathrm{mol}$ to $30.48 \mathrm{~kJ} / \mathrm{mol}$, depending on the dehydration conditions. The dehydration conditions had no significant effect $(P>0.05)$ on the rehydration properties of instant whole beans.
\end{abstract}

\section{Introduction}

Beans (Phaseolus vulgaris L.) are an important food in the traditional Mexican diet and also the most important grain legume for human consumption in many regions of the world [1]. The dried seeds from beans have excellent nutritional properties: high levels of protein, fiber, vitamin B complex, iron, and calcium and a low fat content. They have recently been associated with health benefits with their antioxidant capacity and inhibition of carcinogenesis [2]. Compared with other carbohydrate sources, beans have a low glycemic index, which might help people with diabetes mellitus and other chronic degenerative diseases to control their blood glucose level [3].
Beans also contain several antinutritional factors that can easily be eliminated or reduced using techniques such as soaking, dehulling, heating (boiling in water, infrared radiation, and extrusion), fermentation, and sprouting [4]. However, soaking followed by cooking is the most common method for producing edible legume products [5]. Hulling, precooking, canning, dehydration, and extrusion are some of the technologies used to process beans $[6,7]$.

In 2009, the annual per capita consumption of the common bean in Mexico was around $10.3 \mathrm{~kg}$, compared with some countries of the European Union at $2.5 \mathrm{~kg}$ and the United States at $3.5 \mathrm{~kg}$ [8]. At present, the level of consumption of beans is falling because of changes in Mexican society such as urbanism and lifestyle, which affect eating habits 
[9]. The Mexican Department of Economy has reported that the production and consumption of the common bean have decreased over the past 5 years [10].

Time-consuming food preparation has been cited as the main factor to be eliminated to reduce the time of household work and has contributed to more people eating their meals outside the home. Currently, because of this time-related factor, the consumption of beans has decreased and been replaced by less nutritious foods, foods with faster cooking times, and precooked foods [11].

Because of their nutritional and health-promoting properties, the development of value-added products based on beans is being promoted to react to the new market opportunities offered in the functional food and nutraceutical industries $[12,13]$. Processing dry beans into a high-value marketable food product, such as dehydrated precooked beans, is in high demand from the food industry, fast-food restaurants, and consumers. This would improve profits for farmers and food manufacturers. However, the high rate of structural defects (splitting, bursting, or butterflying) of the finished bean products has discouraged their acceptance by consumers and end users [14].

A high rate of dehydration of cooked beans causes the seed coat to split, which could be minimized by using a lower air velocity and temperature during drying. However, few studies have focused on the use of a low air temperature for drying and the impact it has on product quality $[15,16]$. Therefore, the objective of this study is to evaluate the effect of less rapid dehydration conditions on the chemical, physical, and rehydration properties of instant whole beans (Phaseolus vulgaris L. var. Azufrado).

\section{Materials and Methods}

2.1. Plant Material. The bean seeds (Phaseolus vulgaris L. var. Azufrado), highly consumed and most preferred in Mexico [17], used for this study were obtained from the Mercado de Abastos, located at Tepic, NAY, Mexico. The beans were separated from broken, small, and split seeds, dust, and other excess materials, then cleaned, and manually graded by size. The physical properties of the size, shape, and color of the samples of the dry beans, analyzed according to the methods reported by Kaptso et al. [18] and Ulloa et al. [16], are summarized in Table 1 .

2.2. Bean Cooking. Batches of $0.20 \mathrm{~kg}$ beans were washed with tap water. Each batch of beans was blanched in $600 \mathrm{~mL}$ tap water at $96^{\circ} \mathrm{C}$ for $3 \mathrm{~min}$. After blanching, the beans were soaked in $1.4 \mathrm{~L}$ tap water at $45^{\circ} \mathrm{C}$ for $120 \mathrm{~min}$ and then the hydrated beans were cooked in a pot at $97^{\circ} \mathrm{C}$ for $90 \mathrm{~min}$.

2.3. Dehydration of Cooked Beans. The dehydration of the cooked beans was conducted using a $2^{2}$ factorial design, where dehydration air temperature $\left(25^{\circ} \mathrm{C}\right.$ and $\left.30^{\circ} \mathrm{C}\right)$ and dehydration air velocity $(0.5 \mathrm{~m} / \mathrm{s}$ and $1.0 \mathrm{~m} / \mathrm{s})$ were the two factors. Each treatment was repeated three times. The cooked beans were dehydrated in a cabinet dryer, using air at a relative humidity (RH) of $45 \pm 5 \%$, flowing horizontally
TABLE 1: Some physical properties of raw dry bean of Azufrado variety.

\begin{tabular}{lc}
\hline Physical properties & Value $^{\mathrm{x}}$ \\
\hline Weight 100 seeds $(\mathrm{g})$ & $23.52 \pm 0.21$ \\
Length $(\mathrm{mm})$ & $10.61 \pm 0.65$ \\
Width $(\mathrm{mm})$ & $6.83 \pm 0.37$ \\
Thickness $(\mathrm{mm})$ & $4.58 \pm 0.35$ \\
Sphericity & $0.65 \pm 0.02$ \\
Geometric diameter $(\mathrm{mm})$ & $6.98 \pm 0.44$ \\
Color & \\
$L^{*}$ & $61.80 \pm 1.58$ \\
$a^{*}$ & $-0.45 \pm 0.56$ \\
$b^{*}$ & $39.92 \pm 1.82$ \\
\hline
\end{tabular}

${ }^{\mathrm{x}}$ Mean value \pm standard deviation of three determinations.

through the cooked beans. The velocity of the air was measured using a CEM DT-618 thermoanemometer (Shenzhen Everbest Machinery Industry, Co. Ltd, Nanshan, Shenzhen, China). For dehydration, $0.40 \mathrm{~kg}$ of cooked beans was uniformly spread in a single layer on a rectangular tray formed by an aluminum frame $(0.40 \mathrm{~m} \times 0.30 \mathrm{~m})$ and a $1.3 \mathrm{~mm}$ fine plastic mesh. Bean samples were removed from the dryer at intervals of $60 \mathrm{~min}$ during the dehydration process and their weights were recorded using a H-2710 digital scale with $0.01 \mathrm{~g}$ accuracy (Ohaus Corporation, Parsippany, NJ, USA). Dehydration of the cooked beans continued until the decrease in weight was negligible. The final moisture content was considered to be the equilibrium moisture content. The moisture ratio (MR) was calculated using the following equation:

$$
\mathrm{MR}=\frac{M_{t d}-M_{e d}}{M_{0 d}-M_{e d}}
$$

where $M_{t d}$ is the moisture content at any time during dehydration (d.b.); $M_{e d}$ is the equilibrium moisture content (d.b.); and $M_{0 d}$ is the initial moisture content (d.b.).

The experimental dehydration data (MR) was fitted to the models shown in Table 2 [19-23] by means of analysis of nonlinear regression using the Simple-Quasi-Newton method in the Statistica 9.0 software (StatSoft, Inc., Tulsa, USA). The goodness of fit to the experimental data of the tested mathematical models was evaluated using the values of the coefficient of determination $\left(R^{2}\right)$, the root mean square error (RMSE), and the chi-square statistic $\left(\chi^{2}\right)$. The lowest values of RMSE and $\chi^{2}$, with the highest values of $R^{2}(\approx 1.0)$, were considered the optimum criteria to evaluate quality of fit of the models used [19].

2.4. Chemical Composition. The instant whole beans were analyzed for moisture (method 934.01), protein (method 960.52), ash (method 942.05), and fat content (method 920.39), according to the AOAC methods [24]. The percentage of crude protein was estimated by multiplying the total nitrogen content by a factor of 6.25 . The total carbohydrate content was estimated by subtracting the sum of the mean percentage values of water, total ash, crude protein, and crude 
TABLE 2: Thin-layer models applied to dehydration of cooked bean and models applied to rehydration of instant whole bean.

\begin{tabular}{|c|c|c|}
\hline Model & Mathematical equation & Reference \\
\hline \multicolumn{3}{|l|}{ Dehydration } \\
\hline Midilli et al. & $\mathrm{MR}=a \exp \left(-k_{d} t^{n}\right)+b t$ & $\begin{array}{l}\text { Midilli et al. } \\
{[20]}\end{array}$ \\
\hline Page & $\mathrm{MR}=\exp \left(-k_{d} t^{n}\right)$ & $\begin{array}{l}\text { Vega-Gálvez } \\
\text { et al. [21] }\end{array}$ \\
\hline Verma & $\mathrm{MR}=\exp \left(-k_{d} t\right)+(1-a) \exp (g t)$ & $\begin{array}{l}\text { Pardeshi et } \\
\text { al. [22] }\end{array}$ \\
\hline \multicolumn{3}{|l|}{ Rehydration } \\
\hline Peleg & $\mathrm{RR}=W_{0}+\frac{t}{\left(k_{1}+k_{2} t\right)}$ & $\begin{array}{l}\text { Cox et al. } \\
{[19]}\end{array}$ \\
\hline First order & $\mathrm{RR}=W_{e}+\left(W_{0}-W_{e}\right) \exp \left(-k_{r} t\right)$ & $\begin{array}{l}\text { Cox et al. } \\
{[19]}\end{array}$ \\
\hline Sigmoid & $\mathrm{RR}=W_{e}+\frac{W_{e}}{1+\exp \left[-k_{r}(t-\tau)\right]}$ & $\begin{array}{l}\text { Oliveira et } \\
\text { al. [23] }\end{array}$ \\
\hline
\end{tabular}

fat contents from 100. All determinations were carried out in triplicate.

2.5. Physical Properties. The size and shape of the beans were determined by weighing 100 seeds and calculating their sphericity $(S)$ and geometric diameter $\left(D_{g}\right)$. The weight of 100 seeds was determined in triplicate using a digital balance of $0.01 \mathrm{~g}$ accuracy (Ohaus Corporation). From each bean sample, 100 seeds were selected at random and their individual length $(L)$, width $(\mathrm{Wd})$, and thickness $(\mathrm{Ti})$ (the three principal dimensions in three mutually perpendicular directions) were measured using a digital screw gauge with an accuracy of $0.02 \mathrm{~mm}$ (model 500-774; Mitutoyo Co., Kawasaki, Japan). $L$ was defined as the distance from the seed's eye to the opposite end, while Wd and Ti were taken in the two opposite perpendicular directions from the seed's eye to represent the major and minor seed diameters. Using these values of $L, \mathrm{Wd}$, and Ti, $S$ was calculated as $(L \times \mathrm{Wd} \times \mathrm{Ti})^{1 / 3} / L$ and $D_{g}$ as $(L \times \mathrm{Wd} \times \mathrm{Ti})^{1 / 3}[18]$.

The color was measured directly on the surface of each precooked whole bean in a sample of 10 seeds using a Minolta CR-300 color meter (Minolta, Tokyo, Japan). The measured values were expressed according to the CIELAB color scale $L^{*}$ (lightness), $a^{*}$ (redness-greenness), and $b^{*}$ (yellownessblueness). The $L^{*}, a^{*}$, and $b^{*}$ values of the white standard tile used as reference were $97.14,0.19$, and 1.84 , respectively.

Water activity $\left(a_{w}\right)$ was measured in triplicate at $25^{\circ} \mathrm{C}$ using a Decagon AquaLab meter CX-2 (Pullman, WA, USA), on coarse powder samples $(3 \mathrm{~g})$, which were obtained by grinding precooked whole beans using a mortar and pestle. Before testing samples, the water activity meter was turned on and allowed to warm up for $30 \mathrm{~min}$ and calibrated by filling a plastic disposable cup half full with a saturated sodium chloride solution. The accuracy of the measured $a_{w}$ values was \pm 0.003 .

The integrity of the instant whole beans was determined by the presence of split or butter flied beans. Instant whole beans were judged to be split if they had either a crack between the cotyledons or a transverse fissure in the seed coat more than $2 \mathrm{~mm}$ wide. The beans with split seed coats or cracked cotyledons in each batch were counted. The results are reported as the percentage of split beans in a sample of 100 instant whole beans. Butterflied beans have been defined as those with two cotyledons separated by more than half of $L$ of the bean [25].

2.6. Rehydration Characteristics. A sample of 25 beans (weighed them exactly to be fairly close to $10 \mathrm{~g}$ ) without structural damage was placed in a net basket and immersed in a $1 \mathrm{~L}$ glass jar with a lid containing $1 \mathrm{~L}$ distilled water, which had been previously heated to the required soaking temperature $\left(40^{\circ} \mathrm{C}, 60^{\circ} \mathrm{C}\right.$, or $\left.80^{\circ} \mathrm{C}\right)$ in a water bath thermostatically controlled at the required temperature $\left( \pm 1^{\circ} \mathrm{C}\right)$. Water absorption was determined using a digital scale (Ohaus Corporation, Parsippany, NJ, USA) as the increase in the bean weight recorded every $3 \mathrm{~min}$ until the difference between consecutive weight measurements was insignificant $(0.05 \pm 0.01 \mathrm{~g})$. This was considered to represent the point of saturation moisture content. There was no correction for lost solids. After the specified soaking time, the beans were removed from the soaking solution, drained in a kitchen strainer for $0.5 \mathrm{~min}$, blotted with paper tissue, and weighed. The weight gain was measured, and the beans were returned to the soaking solution at the required temperature. All soaking tests were in triplicate and recorded as the percentage moisture (d.b.).

The rehydration ratio (RR) was calculated according to the following equation:

$$
\mathrm{RR}=\frac{W_{r}}{W_{d}},
$$

where $W_{r}$ is the weight after rehydration (g) and $W_{d}$ is the weight of the dried material.

The experimental rehydration data (RR) was fitted to the models shown in Table 2 by means of analysis of nonlinear regression with Statistica 9.0 software as before, using the same criteria for goodness of fit of the tested mathematical models to the experimental data.

The effective diffusivity $\left(D_{\text {eff }}\right)$ and energy of activation $\left(E_{a}\right)$ were determined according to the procedures reported by Kaptso et al. [18].

The water absorption capacity (WAC), dry basis holding capacity (DHC), and rehydration ability (RA) were used as indices to estimate the rehydration characteristics of the instant whole bean at $80^{\circ} \mathrm{C}$, according to the equations reported by Markowski and Zielińska [26]:

$$
\begin{gathered}
\text { WAC }=\frac{M_{r}\left(100-s_{r}\right)-M_{d}\left(100-s_{d}\right)}{M_{0}\left(100-s_{0}\right)-M_{d}\left(100-s_{d}\right)}, \\
\mathrm{DCH}=\frac{M_{r} s_{r}}{M_{d} s_{d}}, \\
\mathrm{RA}=\mathrm{WAC} \cdot \mathrm{DHC},
\end{gathered}
$$

where $M$ and $s$ denote mass of a sample and percent dry matter content of a sample $(0, d$, and $r$ : initial, dried, and rehydrated), respectively. 

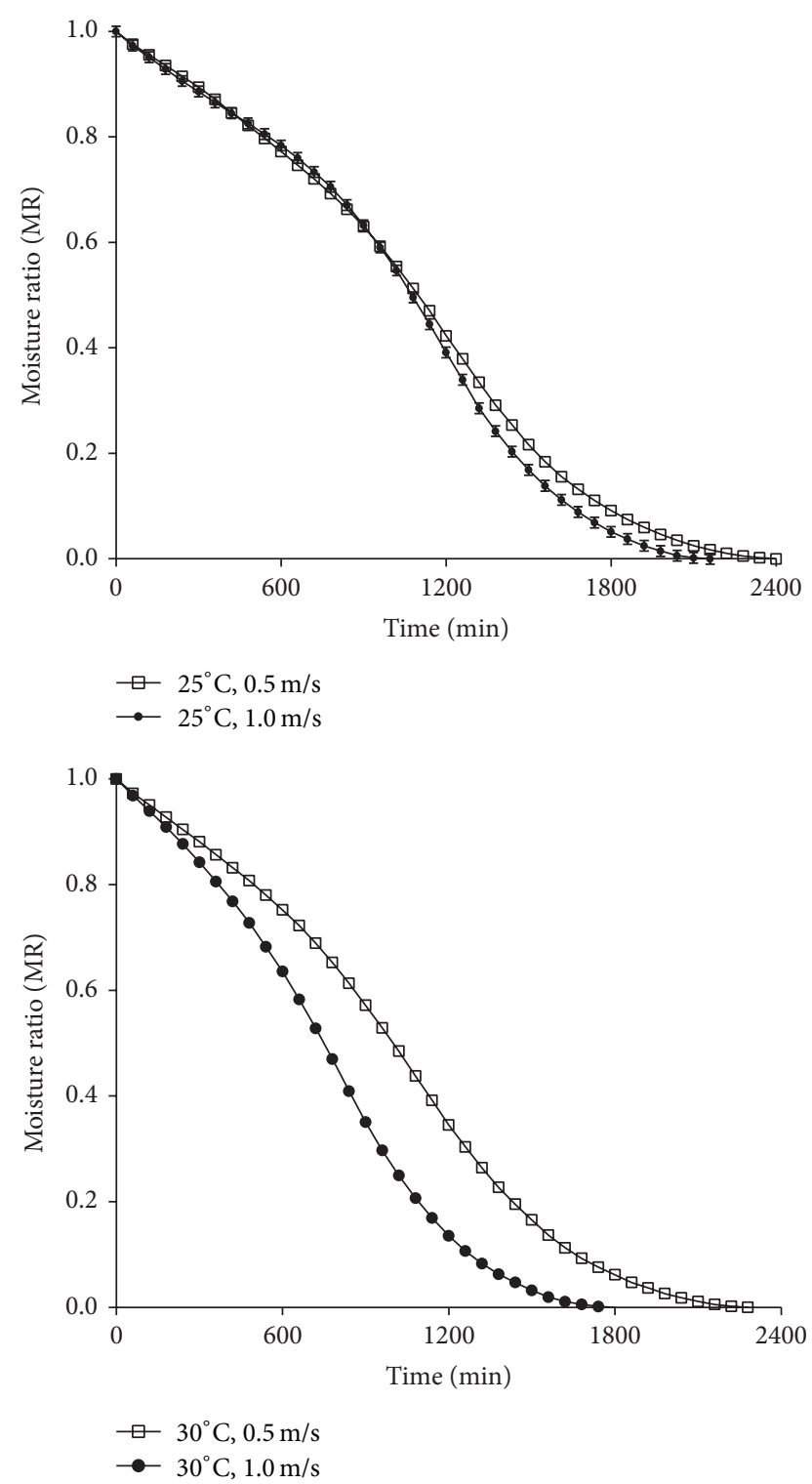

FIGURE 1: Effect of dehydration conditions on the moisture ratio of cooked bean.

2.7. Statistical Analysis. Statistica software (version 9.0) was used for all statistical analyses. Analysis of variance (ANOVA) and Tukey's mean comparison test were used to determine the significance of differences between the treatments at a level of $P<0.05$. Each treatment was evaluated using at least three determinations and each test from data in triplicate.

\section{Results and Discussion}

3.1. Dehydration Kinetics. The initial moisture content of the cooked beans used in the dehydration experiment was $2.03 \mathrm{~kg}$ $\mathrm{H}_{2} \mathrm{O} / \mathrm{kg}$ d.b. (67\% w.b.) and after dehydration was $0.14 \mathrm{~kg}$ $\mathrm{H}_{2} \mathrm{O} / \mathrm{kg}$ d.b. for drying at $25^{\circ} \mathrm{C}$ and $0.5 \mathrm{~m} / \mathrm{s}, 0.13 \mathrm{~kg} \mathrm{H} \mathrm{H}_{2} \mathrm{O} / \mathrm{kg}$ d.b. at $30^{\circ} \mathrm{C}$ and $1.0 \mathrm{~m} / \mathrm{s}, 0.12 \mathrm{~kg} \mathrm{H}_{2} \mathrm{O} / \mathrm{kg}$ d.b. at $25^{\circ} \mathrm{C}$ and $0.5 \mathrm{~m} / \mathrm{s}$, and $0.12 \mathrm{~kg} \mathrm{H}$ O $/ \mathrm{kg} \mathrm{d.b}$. at $30^{\circ} \mathrm{C}$ and $1.0 \mathrm{~m} / \mathrm{s}$. This represents reductions of $78.1 \%, 80.0 \%, 81.0 \%$, and $81.0 \%$, respectively. MR as a function of dehydration time is shown in Figure 1. MR decreased with time to a value of 0 in 27$40 \mathrm{~h}$ depending on the dehydration conditions. At $25^{\circ} \mathrm{C}$, a reduction of $10 \%$ in the dehydration time was observed when the air velocity increased from $0.5 \mathrm{~m} / \mathrm{s}$ to $1.0 \mathrm{~m} / \mathrm{s}$, while at $30^{\circ} \mathrm{C}$ the reduction was $28.9 \%$ for the same increase in air velocity. The decrease in dehydration time with increasing air temperature and air velocity has been reported for many agricultural products [27-30].

The dehydration data obtained from the experiments were fitted using the three thin-layer dehydration models mentioned in Table 2. The kinetic parameters and statistical results from the models are summarized in Table 3 . The best model describing the thin-layer dehydration characteristics of cooked beans was selected as the one with the highest $R^{2}$ values and the lowest $\chi^{2}$ and RMSE values. Of the three models tested, Page's model gave the highest value of $R^{2}$ and the lowest values of $\chi^{2}$ and RMSE for the different conditions for dehydrating cooked beans, which agrees with results obtained for dehydration of other foodstuffs $[17,31]$.

3.2. Chemical Composition. The effect of the conditions of dehydration on the chemical composition of the cooked beans is shown in Table 4. According to these results, protein, the fat, and ash contents were not significantly affected $(P>$ 0.05 ) by the dehydration conditions. However, the moisture content was only higher (by $1.84 \%$ ) where cooked beans dehydrated at $25^{\circ} \mathrm{C}$ and $0.5 \mathrm{~m} / \mathrm{s}$ were compared with those dehydrated at $30^{\circ} \mathrm{C}$ and $1.0 \mathrm{~m} / \mathrm{s}$. The chemical composition of the instant whole beans determined in the present study was in the range of values reported for precooked whole beans in other studies $[32,33]$.

3.3. Physical Characteristics. Table 5 shows the physical characteristics of the instant whole beans. The weight of 100 seeds, the dimensions $L, \mathrm{Wd}, \mathrm{Ti}, S$, and $D_{g}$, and color $\left(L^{*}\right.$, $a^{*}, b^{*}$ ) of the instant whole beans were not significantly affected $(P>0.05)$ by the conditions of dehydration used for their preparation. Of all the physical properties of the instant whole beans, only $a_{w}$ and the percentage of split beans were significantly affected $(P<0.05)$ by the dehydration conditions. The higher dehydration air temperature and air velocity produced a lower value of $a_{w}$ and a higher level of splitting in the instant whole bean. However, the values of $a_{w}$ obtained under dehydration conditions of $25^{\circ} \mathrm{C}$ and $1.0 \mathrm{~m} / \mathrm{s}$ and $30^{\circ} \mathrm{C}$ and $0.5-1.0 \mathrm{~m} / \mathrm{s}$ were below or at the limit value, $a_{w}<0.66$, where no microbial growth will occur [16].

Regarding the integrity of instant whole beans, the dehydration conditions of $30^{\circ} \mathrm{C}$ and $1.0 \mathrm{~m} / \mathrm{s}$ for air temperature and air velocity, respectively, produced a value for splitting of $5.87 \%( \pm 0.65)$, which was significantly higher $(P<0.05)$ than the values obtained under the other dehydration conditions. No butterflying was observed in the instant whole beans dehydrated under any conditions used in this experiment. Splitting and butterflying are caused by differential rates of drying between the skin and the cotyledon. The skin dries rapidly, causing the beans to shrink, resulting in splitting or butterflying, which could be reduced by using a lower 
TABLE 3: Kinetic parameters of the different mathematical models fitted to the experimental data during the dehydration of cooked bean from Azufrado variety.

\begin{tabular}{lclrrr}
\hline Model & Dehydration conditions & Constants & RMSE & $\chi^{2}$ & $R^{2}$ \\
\hline \multirow{4}{*}{ Page } & $25^{\circ} \mathrm{C}, 0.5 \mathrm{~m} / \mathrm{s}$ & $k_{d}=-0.0007 ; n=2.3688$ & 0.0310 & 0.5649 & 0.9922 \\
& $25^{\circ} \mathrm{C}, 1.0 \mathrm{~m} / \mathrm{s}$ & $k_{d}=-0.0006 ; n=2.4698$ & 0.0361 & 0.6142 & 0.9897 \\
& $30^{\circ} \mathrm{C}, 0.5 \mathrm{~m} / \mathrm{s}$ & $k_{d}=-0.0010 ; n=2.3109$ & 0.0447 & 0.8352 & 0.9841 \\
& $30^{\circ} \mathrm{C}, 1.0 \mathrm{~m} / \mathrm{s}$ & $k_{d}=-0.0020 ; n=2.2046$ & 0.0256 & 0.3228 & 0.9943 \\
\hline \multirow{3}{*}{ Midilli et al. } & $25^{\circ} \mathrm{C}, 0.5 \mathrm{~m} / \mathrm{s}$ & $a=1.0728 ; k_{d}=0.0876 ; n=2.5 \times 10^{-6} ; b=-0.029$ & 0.0580 & 1.1723 & 0.9722 \\
& $25^{\circ} \mathrm{C}, 1.0 \mathrm{~m} / \mathrm{s}$ & $a=0.7673 ; k_{d}=-0.2052 ; n=0.3305 ; b=-0.0357$ & 0.0575 & 0.9684 & 0.9730 \\
& $30^{\circ} \mathrm{C}, 0.5 \mathrm{~m} / \mathrm{s}$ & $a=0.7673 ; k_{d}=-0.2052 ; n=0.3305 ; b=-0.0357$ & 0.0440 & 0.8472 & 0.9840 \\
& $30^{\circ} \mathrm{C}, 1.0 \mathrm{~m} / \mathrm{s}$ & $a=0.5312 ; k_{d}=-0.5931 ; n=2.0953 ; b=-0.0009$ & 0.0264 & 0.3293 & 0.9942 \\
\hline \multirow{3}{*}{ Verma } & $25^{\circ} \mathrm{C}, 0.5 \mathrm{~m} / \mathrm{s}$ & $a=-0.0302 ; b=0.0001$ & 0.0591 & 1.1647 & 0.9749 \\
& $25^{\circ} \mathrm{C}, 1.0 \mathrm{~m} / \mathrm{s}$ & $a=-0.0263 ; b=-0.0001$ & 0.0624 & 1.1173 & 0.9696 \\
& $30^{\circ} \mathrm{C}, 0.5 \mathrm{~m} / \mathrm{s}$ & $a=-0.0324 ; b=0.0001$ & 0.0678 & 1.4825 & 0.9643 \\
& $30^{\circ} \mathrm{C}, 1.0 \mathrm{~m} / \mathrm{s}$ & $a=-0.0459 ; b=0.0003$ & 0.0583 & 0.8165 & 0.9755 \\
\hline
\end{tabular}

TABLE 4: Effect of the conditions of dehydration on the chemical composition of instant whole bean of Azufrado variety.

\begin{tabular}{|c|c|c|c|c|}
\hline \multirow{2}{*}{ Component (g/100 g) } & \multicolumn{4}{|c|}{ Conditions of dehydration $^{\mathrm{x}}$} \\
\hline & $25^{\circ} \mathrm{C}, 0.5 \mathrm{~m} / \mathrm{s}$ & $25^{\circ} \mathrm{C}, 1.0 \mathrm{~m} / \mathrm{s}$ & $30^{\circ} \mathrm{C}, 0.5 \mathrm{~m} / \mathrm{s}$ & $30^{\circ} \mathrm{C}, 1.0 \mathrm{~m} / \mathrm{s}$ \\
\hline Moisture & $12.78 \pm 0.29^{\mathrm{a}}$ & $11.82 \pm 0.57^{\mathrm{ab}}$ & $11.26 \pm 0.13^{\mathrm{b}}$ & $10.94 \pm 0.55^{\mathrm{b}}$ \\
\hline Protein $(\mathrm{N} \times 6.25)$ & $24.57 \pm 0.36^{\mathrm{a}}$ & $24.98 \pm 0.04^{\mathrm{a}}$ & $24.23 \pm 1.06^{\mathrm{a}}$ & $22.75 \pm 0.93^{\mathrm{a}}$ \\
\hline Fat & $1.61 \pm 0.06^{\mathrm{a}}$ & $1.64 \pm 0.04^{\mathrm{a}}$ & $1.61 \pm 0.05^{\mathrm{a}}$ & $1.67 \pm 0.06^{\mathrm{a}}$ \\
\hline Ash & $2.26 \pm 0.02^{\mathrm{a}}$ & $2.27 \pm 0.03^{\mathrm{a}}$ & $2.22 \pm 0.08^{\mathrm{a}}$ & $2.23 \pm 0.06^{\mathrm{a}}$ \\
\hline Total carbohydrates & $58.78 \pm 0.61^{\mathrm{a}}$ & $59.29 \pm 0.42^{\mathrm{a}}$ & $60.02 \pm 0.61^{\mathrm{b}}$ & $61.75 \pm 0.52^{\mathrm{b}}$ \\
\hline
\end{tabular}

${ }^{\mathrm{x}}$ Values are averages \pm standard deviation of three samples measured in each experiment repeated three times. Mean values within the same line followed by the same superscript lowercase letter are not significantly different $(P<0.05)$.

TABLE 5: Effect of the conditions of dehydration on some physical properties of instant whole bean of Azufrado variety.

\begin{tabular}{|c|c|c|c|c|}
\hline \multirow{2}{*}{ Physical properties } & \multicolumn{4}{|c|}{ Conditions of dehydration ${ }^{\mathrm{x}}$} \\
\hline & $25^{\circ} \mathrm{C}, 0.5 \mathrm{~m} / \mathrm{s}$ & $25^{\circ} \mathrm{C}, 1.0 \mathrm{~m} / \mathrm{s}$ & $30^{\circ} \mathrm{C}, 0.5 \mathrm{~m} / \mathrm{s}$ & $30^{\circ} \mathrm{C}, 1.0 \mathrm{~m} / \mathrm{s}$ \\
\hline Weight 100 seeds (g) & $21.02 \pm 0.55^{\mathrm{a}}$ & $20.98 \pm 0.71^{\mathrm{a}}$ & $19.99 \pm 0.61^{\mathrm{a}}$ & $19.98 \pm 0.68^{\mathrm{a}}$ \\
\hline Length $(\mathrm{mm})$ & $1.07 \pm 0.03^{\mathrm{a}}$ & $1.07 \pm 0.04^{\mathrm{a}}$ & $1.08 \pm 0.04^{\mathrm{a}}$ & $1.08 \pm 0.04^{\mathrm{a}}$ \\
\hline Width (mm) & $0.65 \pm 0.04^{\mathrm{a}}$ & $0.66 \pm 0.04^{\mathrm{a}}$ & $0.66 \pm 0.03^{\mathrm{a}}$ & $0.65 \pm 0.03^{\mathrm{a}}$ \\
\hline Thickness (mm) & $0.51 \pm 0.02^{\mathrm{a}}$ & $0.52 \pm 0.03^{\mathrm{a}}$ & $0.50 \pm 0.03^{\mathrm{b}}$ & $0.50 \pm 0.02^{\mathrm{a}}$ \\
\hline Sphericity & $0.66 \pm 0.01^{\mathrm{a}}$ & $0.67 \pm 0.02^{\mathrm{a}}$ & $0.66 \pm 0.01^{\mathrm{a}}$ & $0.66 \pm 0.02^{\mathrm{a}}$ \\
\hline Geometric diameter (mm) & $0.71 \pm 0.02^{\mathrm{a}}$ & $0.72 \pm 0.03^{\mathrm{a}}$ & $0.71 \pm 0.02^{\mathrm{a}}$ & $0.71 \pm 0.02^{\mathrm{a}}$ \\
\hline \multicolumn{5}{|l|}{ Color } \\
\hline$L^{*}$ & $45.42 \pm 6.94^{\mathrm{a}}$ & $42.10 \pm 4.72^{\mathrm{a}}$ & $42.60 \pm 5.15^{\mathrm{a}}$ & $44.89 \pm 2.61^{\mathrm{a}}$ \\
\hline$a^{*}$ & $7.62 \pm 0.57^{\mathrm{a}}$ & $7.71 \pm 0.68^{\mathrm{a}}$ & $7.95 \pm 0.78^{\mathrm{a}}$ & $7.79 \pm 0.70^{\mathrm{a}}$ \\
\hline$b^{*}$ & $29.12 \pm 3.16^{\mathrm{a}}$ & $29.62 \pm 2.2^{\mathrm{a}}$ & $25.22 \pm 4.65^{\mathrm{a}}$ & $29.54 \pm 0.67^{\mathrm{a}}$ \\
\hline Water activity & $0.67 \pm 0.01^{\mathrm{a}}$ & $0.66 \pm 0.01^{\mathrm{a}}$ & $0.63 \pm 0.01^{\mathrm{b}}$ & $0.58 \pm 0.01^{\mathrm{c}}$ \\
\hline Splitting (\%) & $2.90 \pm 0.36^{\mathrm{b}}$ & $3.93 \pm 0.90^{\mathrm{b}}$ & $2.91 \pm 0.51^{\mathrm{b}}$ & $5.87 \pm 0.65^{\mathrm{a}}$ \\
\hline
\end{tabular}

${ }^{\mathrm{x}}$ Values are averages \pm standard deviation of three samples measured in each experiment repeated three times. Mean values within the same line followed by the same superscript lowercase letter are not significantly different $(P<0.05)$.

air velocity and temperature during dehydration [14], as was demonstrated in the present study.

3.4. Rehydration Characteristics. The kinetics of water absorption of the instant whole beans as affected by the dehydration temperatures of $40^{\circ} \mathrm{C}, 60^{\circ} \mathrm{C}$, and $80^{\circ} \mathrm{C}$ as rehydration temperatures is shown in Figure 2. The kinetics exhibited initially a high rate of water absorption followed by progressively lower uptake rates at later stages. In addition, at a higher rehydration temperature a lower rehydration time was observed. The rapid initial water uptake by legumes has been attributed to the filling of capillaries on the surface of 
TABle 6: Water absorption characteristics of instant whole bean obtained at different conditions of dehydration using Peleg's model.

\begin{tabular}{|c|c|c|c|c|c|}
\hline \multirow{3}{*}{$\begin{array}{l}\text { Soaking } \\
\text { temperature }\end{array}$} & \multirow{3}{*}{ Kinetic parameters } & \multicolumn{4}{|c|}{ Dehydration conditions ${ }^{\mathrm{x}}$} \\
\hline & & \multicolumn{2}{|c|}{$25^{\circ} \mathrm{C}$} & \multicolumn{2}{|c|}{$30^{\circ} \mathrm{C}$} \\
\hline & & $0.5 \mathrm{~m} / \mathrm{s}$ & $1.0 \mathrm{~m} / \mathrm{s}$ & $0.5 \mathrm{~m} / \mathrm{s}$ & $1.0 \mathrm{~m} / \mathrm{s}$ \\
\hline \multirow{7}{*}{$40^{\circ} \mathrm{C}$} & $W_{\text {obs-eq }}\left(\mathrm{kg} \mathrm{H}_{2} \mathrm{O} / \mathrm{kg}\right.$ d.b. $)$ & $1.29 \pm 0.02^{\mathrm{abA}}$ & $1.24 \pm 0.03^{\mathrm{aA}}$ & $1.33 \pm 0.03^{\mathrm{bcA}}$ & $1.37 \pm 0.02^{\mathrm{cA}}$ \\
\hline & $W_{\text {eq }}\left(\mathrm{kg} \mathrm{H}_{2} \mathrm{O} / \mathrm{kg}\right.$ d.b. $)$ & $1.50 \pm 0.03^{\mathrm{bB}}$ & $1.37 \pm 0.03^{\mathrm{aB}}$ & $1.56 \pm 0.03^{\mathrm{bcB}}$ & $1.59 \pm 0.02^{\mathrm{cB}}$ \\
\hline & $k_{1}\left(\mathrm{~min} /\left[\mathrm{kg} \mathrm{H}{ }_{2} \mathrm{O} / \mathrm{kg}\right.\right.$ d.b.] $)$ & $3.78 \pm 0.03^{\mathrm{b}}$ & $2.50 \pm 0.04^{\mathrm{a}}$ & $3.84 \pm 0.03^{\mathrm{bc}}$ & $3.92 \pm 0.05^{\mathrm{c}}$ \\
\hline & $k_{2}\left(\mathrm{~kg} \mathrm{H}_{2} \mathrm{O} / \mathrm{kg} \mathrm{d.b.}\right)^{-1}$ & $0.66 \pm 0.03^{\mathrm{ab}}$ & $0.72 \pm 0.02^{\mathrm{b}}$ & $0.64 \pm 0.02^{\mathrm{a}}$ & $0.63 \pm 0.02^{\mathrm{a}}$ \\
\hline & $R^{2}$ & 0.9998 & 0.9993 & 0.9997 & 0.9998 \\
\hline & $\chi^{2}$ & 0.0060 & 0.0139 & 0.0063 & 0.0025 \\
\hline & RMSE & 0.0232 & 0.0345 & 0.0223 & 0.0106 \\
\hline \multirow{7}{*}{$60^{\circ} \mathrm{C}$} & $W_{\text {obs-eq }}\left(\mathrm{kg} \mathrm{H}_{2} \mathrm{O} / \mathrm{kg} \mathrm{d.b.}\right)$ & $1.38 \pm 0.03^{\mathrm{bA}}$ & $1.31 \pm 0.03^{\mathrm{aA}}$ & $1.47 \pm 0.02^{\mathrm{cA}}$ & $1.43 \pm 0.02^{\mathrm{bA}}$ \\
\hline & $W_{\text {eq }}\left(\mathrm{kg} \mathrm{H}_{2} \mathrm{O} / \mathrm{kg}\right.$ d.b. $)$ & $1.48 \pm 0.04^{\mathrm{bB}}$ & $1.37 \pm 0.03^{\mathrm{aA}}$ & $1.62 \pm 0.03^{\mathrm{cB}}$ & $1.58 \pm 0.03^{\mathrm{cB}}$ \\
\hline & $k_{1}\left(\mathrm{~min} /\left[\mathrm{kg} \mathrm{H} \mathrm{H}_{2} \mathrm{O} / \mathrm{kg}\right.\right.$ d.b. $\left.]\right)$ & $1.26 \pm 0.03^{\mathrm{b}}$ & $0.80 \pm 0.04^{\mathrm{a}}$ & $1.59 \pm 0.03^{\mathrm{c}}$ & $1.69 \pm 0.04^{\mathrm{d}}$ \\
\hline & $k_{2}\left(\mathrm{~kg} \mathrm{H}_{2} \mathrm{O} / \mathrm{kg} \mathrm{d.b.}\right)^{-1}$ & $0.67 \pm 0.02^{\mathrm{b}}$ & $0.73 \pm 0.03^{c}$ & $0.61 \pm 0.02^{\mathrm{a}}$ & $0.63 \pm 0.03^{\mathrm{ab}}$ \\
\hline & $R^{2}$ & 0.9999 & 0.9998 & 0.9996 & 0.9999 \\
\hline & $\chi^{2}$ & 0.0039 & 0.0010 & 0.0106 & 0.0071 \\
\hline & RMSE & 0.0231 & 0.0111 & 0.0321 & 0.0223 \\
\hline \multirow{7}{*}{$80^{\circ} \mathrm{C}$} & $W_{\text {obs-eq }}\left(\mathrm{kg} \mathrm{H}_{2} \mathrm{O} / \mathrm{kg}\right.$ d.b. $)$ & $1.45 \pm 0.03^{\mathrm{abA}}$ & $1.41 \pm 0.02^{\mathrm{aA}}$ & $1.50 \pm 0.02^{\mathrm{bA}}$ & $1.48 \pm 0.03^{\mathrm{bA}}$ \\
\hline & $W_{\text {eq }}\left(\mathrm{kg} \mathrm{H}_{2} \mathrm{O} / \mathrm{kg}\right.$ d.b. $)$ & $1.52 \pm 0.03^{\mathrm{abB}}$ & $1.47 \pm 0.02^{\mathrm{aB}}$ & $1.58 \pm 0.03^{\mathrm{bcB}}$ & $1.60 \pm 0.03^{\mathrm{cA}}$ \\
\hline & $k_{1}\left(\min /\left[\operatorname{kg~H} \mathrm{H}_{2} \mathrm{O} / \mathrm{kg}\right.\right.$ d.b. $\left.]\right)$ & $0.66 \pm 0.02^{\mathrm{b}}$ & $0.58 \pm 0.02^{\mathrm{a}}$ & $0.64 \pm 0.02^{\mathrm{b}}$ & $0.95 \pm 0.03^{\mathrm{c}}$ \\
\hline & $k_{2}\left(\mathrm{~kg} \mathrm{H}_{2} \mathrm{O} / \mathrm{kg} \text { d.b. }\right)^{-1}$ & $0.66 \pm 0.02^{\mathrm{ab}}$ & $0.68 \pm 0.02^{\mathrm{b}}$ & $0.63 \pm 0.02^{\mathrm{a}}$ & $0.63 \pm 0.02^{\mathrm{a}}$ \\
\hline & $R^{2}$ & 0.9998 & 0.9997 & 0.998 & 0.9998 \\
\hline & $\chi^{2}$ & 0.0032 & 0.00027 & 0.0015 & 0.0014 \\
\hline & RMSE & 0.0144 & 0.0085 & 0.0143 & 0.0136 \\
\hline
\end{tabular}

${ }^{\mathrm{x}}$ Values are averages \pm standard deviation of three samples measured in each experiment repeated three times. The values with the same superscript lowercase letter along the lines are not significantly different $(P<0.05)$, while values with the same superscript uppercase letter in the column for each temperature are not significantly different $(P<0.05)$.

the seed coats and at the hilum [16]. The decline in rehydration rates at later stages is related to the combined effects of increased extraction rates of soluble materials and lower water absorption, presumably because of the water filling the free capillaries and intermicellar spaces. Subsequently, the amounts of water absorbed with further rehydration were minimal until equilibrium was attained, which signaled the maximum water capacity of the instant whole bean. Similar rehydration patterns have been reported in many foodstuffs [34-36].

The kinetic parameters of dehydration and the statistical results from the mathematical models mentioned in Table 2 for instant whole beans are summarized in Tables 6-8. Of the three models tested, Peleg's model gave the highest values of $R^{2}$ and lowest values of $\chi^{2}$ and RMSE, followed by the First Order and Sigmoid models. However, the predicted equilibrium moisture content $\left(W_{\mathrm{eq}}\right)$ at each rehydration temperature for the First Order and Sigmoid models in general was not significantly different $(P>0.05)$ from the observed equilibrium moisture content $\left(W_{\text {obs-eq }}\right)$. This was not the case with Peleg's model, which showed significant differences $(P<0.05)$ between the predicted and observed equilibrium moisture contents. Higher temperatures resulted in an increase in the magnitude of absorbed water in the instant whole beans obtained under different dehydration conditions. Similar behavior has been observed in other food systems [19]. The higher values of $W_{\text {obs-eq }}$ were 1.50 and $1.48 \mathrm{~kg} \mathrm{H} \mathrm{H}_{2} \mathrm{O} / \mathrm{kg}$ d.b., corresponding to instant whole beans dehydrated at $30^{\circ} \mathrm{C}$ and $0.5 \mathrm{~m} / \mathrm{s}$ and $30^{\circ} \mathrm{C}$ and $1.0 \mathrm{~m} / \mathrm{s}$, respectively (Tables 6-8). According to Reyes et al. [37], the value of $W_{\text {obs-eq }}$ for slices of dehydrated mushrooms in a hybrid-solar dryer after rehydration in water at $30^{\circ} \mathrm{C}$ was $1.91 \mathrm{~kg} \mathrm{H}{ }_{2} \mathrm{O} / \mathrm{kg}$ d.b.

In contrast, the First Order and Sigmoid models produced a constant rate of rehydration, $k_{r}$, which increased with rehydration temperature in agreement with studies on kidney beans and cowpeas [18], and varied significantly $(P<$ 0.05 ) with the dehydration conditions but without a defined behavior (Tables 7 and 8). Regarding Peleg's model, the second constant, $k_{2}$, which has been shown to be linked to the maximum water absorption capacity of the seeds, did not vary with temperature, while for the first constant, $k_{1}$, the reverse effect of temperature has been observed [18]. At each rehydration temperature, higher values of $k_{1}$ were observed for instant whole beans dehydrated at an air temperature of $30^{\circ} \mathrm{C}$.

The effect of rehydration temperature on the $D_{\text {eff }}$ of water in the instant whole beans dehydrated under different 
TABLE 7: Water absorption characteristics of instant whole bean obtained at different conditions of dehydration using the First Order model.

\begin{tabular}{|c|c|c|c|c|c|}
\hline \multirow{3}{*}{$\begin{array}{l}\text { Soaking } \\
\text { temperature }\end{array}$} & \multirow{3}{*}{ Kinetic parameters } & \multicolumn{4}{|c|}{ Dehydration conditions ${ }^{\mathrm{x}}$} \\
\hline & & \multicolumn{2}{|c|}{$25^{\circ} \mathrm{C}$} & \multicolumn{2}{|c|}{$30^{\circ} \mathrm{C}$} \\
\hline & & $0.5 \mathrm{~m} / \mathrm{s}$ & $1.0 \mathrm{~m} / \mathrm{s}$ & $0.5 \mathrm{~m} / \mathrm{s}$ & $1.0 \mathrm{~m} / \mathrm{s}$ \\
\hline \multirow{7}{*}{$40^{\circ} \mathrm{C}$} & $W_{\text {obs-eq }}\left(\mathrm{kg} \mathrm{H}_{2} \mathrm{O} / \mathrm{kg} \mathrm{d.b.}\right)$ & $1.29 \pm 0.03^{\mathrm{aA}}$ & $1.24 \pm 0.03^{\mathrm{aA}}$ & $1.33 \pm 0.02^{\mathrm{bA}}$ & $1.37 \pm 0.02^{\mathrm{bA}}$ \\
\hline & $W_{\mathrm{eq}}\left(\mathrm{kg} \mathrm{H}_{2} \mathrm{O} / \mathrm{kg}\right.$ d.b. $)$ & $1.29 \pm 0.04^{\mathrm{aA}}$ & $1.23 \pm 0.02^{\mathrm{aA}}$ & $1.33 \pm 0.03^{\mathrm{bA}}$ & $1.36 \pm 0.03^{\mathrm{bA}}$ \\
\hline & $k_{1}\left(\min ^{-1}\right)$ & $0.13 \pm 0.01^{\mathrm{a}}$ & $0.19 \pm 0.01^{\mathrm{b}}$ & $0.13 \pm 0.01^{\mathrm{a}}$ & $0.12 \pm 0.01^{\mathrm{a}}$ \\
\hline & $k_{0}\left(\min ^{-1} \mathrm{~kg} \mathrm{H}_{2} \mathrm{O} / \mathrm{kg}\right.$ d.b. $)$ & $0.17 \pm 0.01^{\mathrm{a}}$ & $0.24 \pm 0.01^{\mathrm{b}}$ & $0.17 \pm 0.01^{\mathrm{a}}$ & $0.17 \pm 0.01^{\mathrm{a}}$ \\
\hline & $R^{2}$ & 0.9998 & 0.9998 & 0.9997 & 0.9995 \\
\hline & $\chi^{2}$ & 0.0284 & 0.0104 & 0.0305 & 0.0623 \\
\hline & RMSE & 0.0245 & 0.0149 & 0.0292 & 0.0306 \\
\hline \multirow{7}{*}{$60^{\circ} \mathrm{C}$} & $W_{\text {obs-eq }}\left(\mathrm{kg} \mathrm{H}_{2} \mathrm{O} / \mathrm{kg}\right.$ d.b. $)$ & $1.38 \pm 0.02^{\mathrm{bA}}$ & $1.31 \pm 0.03^{\mathrm{aA}}$ & $1.47 \pm 0.03^{\mathrm{cA}}$ & $1.43 \pm 0.04^{\mathrm{cA}}$ \\
\hline & $W_{\text {eq }}\left(\mathrm{kg} \mathrm{H}_{2} \mathrm{O} / \mathrm{kg}\right.$ d.b. $)$ & $1.36 \pm 0.02^{\mathrm{bA}}$ & $1.29 \pm 0.02^{\mathrm{aA}}$ & $1.46 \pm 0.03^{\mathrm{cA}}$ & $1.42 \pm 0.02^{\mathrm{cA}}$ \\
\hline & $k_{1}\left(\min ^{-1}\right)$ & $0.32 \pm 0.01^{\mathrm{b}}$ & $0.45 \pm 0.02^{\mathrm{c}}$ & $0.25 \pm 0.01^{\mathrm{a}}$ & $0.25 \pm 0.01^{\mathrm{a}}$ \\
\hline & $k_{0}\left(\mathrm{~min}^{-1} \mathrm{~kg} \mathrm{H}{ }_{2} \mathrm{O} / \mathrm{kg}\right.$ d.b. $)$ & $0.43 \pm 0.02^{\mathrm{b}}$ & $0.59 \pm 0.03^{c}$ & $0.37 \pm 0.02^{\mathrm{a}}$ & $0.35 \pm 0.01^{\mathrm{a}}$ \\
\hline & $R^{2}$ & 0.9998 & 0.9989 & 0.9995 & 0.9998 \\
\hline & $\chi^{2}$ & 0.0144 & 0.0119 & 0.0098 & 0.0167 \\
\hline & RMSE & 0.0219 & 0.0215 & 0.0128 & 0.0216 \\
\hline \multirow{7}{*}{$80^{\circ} \mathrm{C}$} & $W_{\text {obs-eq }}\left(\mathrm{kg} \mathrm{H}_{2} \mathrm{O} / \mathrm{kg}\right.$ d.b. $)$ & $1.45 \pm 0.02^{\mathrm{abA}}$ & $1.41 \pm 0.02^{\mathrm{aA}}$ & $1.50 \pm 0.03^{\mathrm{cA}}$ & $1.48 \pm 0.02^{\mathrm{bcA}}$ \\
\hline & $W_{\text {eq }}\left(\mathrm{kg} \mathrm{H}_{2} \mathrm{O} / \mathrm{kg}\right.$ d.b. $)$ & $1.43 \pm 0.02^{\mathrm{abA}}$ & $1.39 \pm 0.02^{\mathrm{aA}}$ & $1.48 \pm 0.02^{\mathrm{cA}}$ & $1.46 \pm 0.02^{\mathrm{bcA}}$ \\
\hline & $k_{1}\left(\min ^{-1}\right)$ & $0.49 \pm 0.02^{\mathrm{b}}$ & $0.54 \pm 0.01^{\mathrm{c}}$ & $0.49 \pm 0.01^{\mathrm{b}}$ & $0.39 \pm 0.01^{\mathrm{a}}$ \\
\hline & $k_{0}\left(\min ^{-1} \mathrm{~kg} \mathrm{H}{ }_{2} \mathrm{O} / \mathrm{kg}\right.$ d.b. $)$ & $0.70 \pm 0.01^{\mathrm{b}}$ & $0.75 \pm 0.02^{\mathrm{c}}$ & $0.72 \pm 0.01^{\mathrm{b}}$ & $0.57 \pm 0.01^{\mathrm{a}}$ \\
\hline & $R^{2}$ & 0.9998 & 0.9998 & 0.9997 & 0.9998 \\
\hline & $\chi^{2}$ & 0.0112 & 0.0085 & 0.0052 & 0.0091 \\
\hline & RMSE & 0.0307 & 0.0309 & 0.0204 & 0.0209 \\
\hline
\end{tabular}

${ }^{\mathrm{x}}$ Values are averages \pm standard deviation of three samples measured in each experiment repeated three times. The values with the same superscript lowercase letter along the lines are not significantly different $(P<0.05)$, while values with the same superscript uppercase letter in the column for each temperature are not significantly different $(P<0.05)$.

conditions, using the $k$-values of the First Order model, is shown in Table 9. From this table, it is possible to verify the increase in $D_{\text {eff }}$ when the temperature is raised, which agrees with the behavior reported in other studies [38, 39]. The values of $D_{\text {eff }}$ were at least two orders of magnitude higher than values reported for other raw seeds and grains [40], probably because during the preparation of instant whole beans, the cooking of the seed modifies the barrier effect of the seed coat and its role in the process of mass exchange [41].

The effect of the dehydration conditions on the natural logarithm of $D_{\text {eff }}$ as a function of the reciprocal of absolute temperature for instant whole beans has been plotted in Figure 3. The results show a linear relationship due to the Arrhenius-type dependence $\left(R^{2}=0.8992-0.9995\right.$, Table 9). From the slope of these lines, $E_{a}$ values were determined ranging from $23.56 \mathrm{KJ} / \mathrm{mol}$ to $30.48 \mathrm{KJ} / \mathrm{mol}$, being slightly lower than those from instant whole beans dehydrated at $30^{\circ} \mathrm{C}$. These values of $E_{a}$ are similar to those found in different agricultural products and correspond to the general range of 15-40 kJ/mol for various food materials [42].

Table 10 shows the values of the DHC, WAC, and RA indices at $80^{\circ} \mathrm{C}$ for the instant whole beans dehydrated under different conditions. According to these results, the different dehydration conditions had no significant effect $(P>0.05)$ on the DHC index and only a small effect on the WAC and RA indices. Taking into account the values of such indices (Table 10), the instant whole beans dehydrated under different conditions had a very high ability to retain total solids during rehydration, to absorb water with respect to the water loss during dehydration, and to rehydrate. Regarding the indices evaluated, their values indicate the low extent of tissue damage caused by the dehydration and rehydration processes [43]. The values of the DHC, WAC, and RA indices for instant whole beans in the present study were high compared with values reported for carrots [22], mushrooms [44], and mango [45], although a fair comparison is difficult because of differences in the experimental and rehydration conditions used.

\section{Conclusions}

Air temperatures of $25^{\circ} \mathrm{C}$ and $30^{\circ} \mathrm{C}$ at 0.5 and $1.0 \mathrm{~m} / \mathrm{s}$ as dehydration conditions were used for the preparation of instant whole beans. The results showed that such dehydration conditions did not significantly affect $(P>0.05)$ the protein, fat, and ash contents, or the rehydration quality at $80^{\circ} \mathrm{C}$ measured using WAC, DHC, and RA indices. However, the higher temperature and air velocity used for dehydration 
TABLE 8: Water absorption characteristics of instant whole bean obtained at different conditions of dehydration using the Sigmoid model.

\begin{tabular}{|c|c|c|c|c|c|}
\hline \multirow{3}{*}{$\begin{array}{l}\text { Soaking } \\
\text { temperature }\end{array}$} & \multirow{3}{*}{ Kinetic parameters } & \multicolumn{4}{|c|}{ Dehydration conditions ${ }^{\mathrm{x}}$} \\
\hline & & \multicolumn{2}{|c|}{$25^{\circ} \mathrm{C}$} & \multicolumn{2}{|c|}{$30^{\circ} \mathrm{C}$} \\
\hline & & $0.5 \mathrm{~m} / \mathrm{s}$ & $1.0 \mathrm{~m} / \mathrm{s}$ & $0.5 \mathrm{~m} / \mathrm{s}$ & $1.0 \mathrm{~m} / \mathrm{s}$ \\
\hline \multirow{7}{*}{$40^{\circ} \mathrm{C}$} & $W_{\text {obs-eq }}\left(\mathrm{kg} \mathrm{H}_{2} \mathrm{O} / \mathrm{kg}\right.$ d.b. $)$ & $1.29 \pm 0.02^{\mathrm{bA}}$ & $1.24 \pm 0.02^{\mathrm{aA}}$ & $1.33 \pm 0.02^{\mathrm{bcA}}$ & $1.37 \pm 0.03^{\mathrm{cA}}$ \\
\hline & $W_{\mathrm{eq}}\left(\mathrm{kg} \mathrm{H}_{2} \mathrm{O} / \mathrm{kg}\right.$ d.b. $)$ & $1.25 \pm 0.02^{\mathrm{abA}}$ & $1.21 \pm 0.02^{\mathrm{aA}}$ & $1.29 \pm 0.02^{\mathrm{bcA}}$ & $1.32 \pm 0.02^{\mathrm{cA}}$ \\
\hline & $k_{r}\left(10^{-2} \min ^{-1}\right)$ & $0.29 \pm 0.01^{\mathrm{b}}$ & $0.45 \pm 0.02^{\mathrm{b}}$ & $0.28 \pm 0.01^{\mathrm{b}}$ & $0.25 \pm 0.01^{\mathrm{a}}$ \\
\hline & $\tau(\min )$ & $5.68 \pm 0.04^{\mathrm{b}}$ & $4.10 \pm 0.03^{\mathrm{a}}$ & $5.89 \pm 0.04^{c}$ & $5.96 \pm 0.05^{\mathrm{d}}$ \\
\hline & $R^{2}$ & 0.9609 & 0.9708 & 0.9609 & 0.9556 \\
\hline & $\chi^{2}$ & 0.2512 & 0.2127 & 0.2614 & 0.3031 \\
\hline & RMSE & 0.0746 & 0.0607 & 0.0789 & 0.0809 \\
\hline \multirow{7}{*}{$60^{\circ} \mathrm{C}$} & $W_{\text {obs-eg }}\left(\mathrm{kg} \mathrm{H}_{2} \mathrm{O} / \mathrm{kg}\right.$ d.b. $)$ & $1.38 \pm 0.02^{\mathrm{bA}}$ & $1.31 \pm 0.02^{\mathrm{aA}}$ & $1.47 \pm 0.02^{\mathrm{dA}}$ & $1.43 \pm 0.02^{\mathrm{cA}}$ \\
\hline & $W_{\mathrm{eq}}\left(\mathrm{kg} \mathrm{H}_{2} \mathrm{O} / \mathrm{kg}\right.$ d.b. $)$ & $1.33 \pm 0.02^{\mathrm{bB}}$ & $1.28 \pm 0.02^{\mathrm{aB}}$ & $1.43 \pm 0.03^{\mathrm{dA}}$ & $1.39 \pm 0.02^{\mathrm{cA}}$ \\
\hline & $k_{r}\left(10^{-2} \min ^{-1}\right)$ & $1.25 \pm 0.01^{\mathrm{c}}$ & $2.07 \pm 0.01^{\mathrm{d}}$ & $0.66 \pm 0.01^{\mathrm{b}}$ & $0.63 \pm 0.01^{\mathrm{a}}$ \\
\hline & $\tau(\min )$ & $2.54 \pm 0.03^{\mathrm{b}}$ & $2.40 \pm 0.02^{\mathrm{a}}$ & $3.13 \pm 0.03^{c}$ & $3.17 \pm 0.03^{c}$ \\
\hline & $R^{2}$ & 0.9725 & 0.9972 & 0.9713 & 0.9729 \\
\hline & $\chi^{2}$ & 0.0939 & 0.0352 & 0.2181 & 0.2257 \\
\hline & RMSE & 0.0631 & 0.0445 & 0.0733 & 0.0845 \\
\hline \multirow{7}{*}{$80^{\circ} \mathrm{C}$} & $W_{\text {obs-eq }}\left(\mathrm{kg} \mathrm{H}_{2} \mathrm{O} / \mathrm{kg} \mathrm{d.b.}\right)$ & $1.45 \pm 0.03^{\mathrm{abA}}$ & $1.41 \pm 0.02^{\mathrm{aA}}$ & $1.50 \pm 0.03^{\mathrm{bA}}$ & $1.48 \pm 0.02^{\mathrm{bA}}$ \\
\hline & $W_{\mathrm{eq}}\left(\mathrm{kg} \mathrm{H}_{2} \mathrm{O} / \mathrm{kg}\right.$ d.b. $)$ & $1.41 \pm 0.02^{\mathrm{abA}}$ & $1.38 \pm 0.02^{\mathrm{aA}}$ & $1.47 \pm 0.02^{\mathrm{cA}}$ & $1.43 \pm 0.02^{\mathrm{bcB}}$ \\
\hline & $k_{r}\left(10^{-2} \min ^{-1}\right)$ & $2.24 \pm 0.01^{\mathrm{b}}$ & $4.06 \pm 0.02^{\mathrm{c}}$ & $2.23 \pm 0.02^{\mathrm{b}}$ & $1.80 \pm 0.02^{\mathrm{a}}$ \\
\hline & $\tau(\min )$ & $2.54 \pm 0.03^{\mathrm{b}}$ & $2.40 \pm 0.02^{\mathrm{a}}$ & $3.13 \pm 0.03^{c}$ & $3.17 \pm 0.02^{c}$ \\
\hline & $R^{2}$ & 0.9957 & 0.9961 & 0.9958 & 0.9889 \\
\hline & $\chi^{2}$ & 0.0213 & 0.0121 & 0.1623 & 0.3419 \\
\hline & RMSE & 0.0531 & 0.0429 & 0.0427 & 0.0521 \\
\hline
\end{tabular}

${ }^{\mathrm{x}}$ Values are averages \pm standard deviation of three samples measured in each experiment repeated three times. The values with the same lowercase letter along the lines are not significantly different $(P<0.05)$, while values with the same uppercase letter in the column for each temperature are not significantly different $(P<0.05)$.

TABle 9: Diffusion coefficient $\left(D_{\text {eff }}\right)$ and activation energy $\left(E_{a}\right)$ for rehydration of instant whole bean obtained at different conditions of dehydration.

\begin{tabular}{|c|c|c|c|c|}
\hline Dehydration conditions & Temperature $\left({ }^{\circ} \mathrm{C}\right)$ & $D_{\text {eff }}\left(\mathrm{m}^{2} / \mathrm{s}\right)^{\mathrm{x}}$ & $E_{a}(\mathrm{Kj} / \mathrm{mol})$ & $R^{2}$ \\
\hline \multirow{3}{*}{$25^{\circ} \mathrm{C}, 0.5 \mathrm{~m} / \mathrm{s}$} & 40 & $2.86 \times 10^{-09}\left( \pm 2.57 \times 10^{-10}\right)^{\mathrm{a}}$ & \multirow{3}{*}{29.97} & \multirow{3}{*}{0.9885} \\
\hline & 60 & $6.74 \times 10^{-09}\left( \pm 1.28 \times 10^{-10}\right)^{b}$ & & \\
\hline & 80 & $1.04 \times 10^{-08}\left( \pm 1.43 \times 10^{-09}\right)^{\mathrm{c}}$ & & \\
\hline \multirow{3}{*}{$25^{\circ} \mathrm{C}, 1.0 \mathrm{~m} / \mathrm{s}$} & 40 & $4.25 \times 10^{-09}\left( \pm 2.59 \times 10^{-10}\right)^{\mathrm{a}}$ & \multirow{3}{*}{23.56} & \multirow{3}{*}{0.8982} \\
\hline & 60 & $9.95 \times 10^{-09}\left( \pm 2.51 \times 10^{-10}\right)^{\mathrm{b}}$ & & \\
\hline & 80 & $1.17 \times 10^{-08}\left( \pm 1.89 \times 10^{-09}\right)^{\mathrm{c}}$ & & \\
\hline \multirow{3}{*}{$30^{\circ} \mathrm{C}, 0.5 \mathrm{~m} / \mathrm{s}$} & 40 & $2.75 \times 10^{-09}\left( \pm 2.31 \times 10^{-10}\right)^{\mathrm{a}}$ & \multirow{3}{*}{30.48} & \multirow{3}{*}{0.9995} \\
\hline & 60 & $5.38 \times 10^{-09}\left( \pm 1.95 \times 10^{-10}\right)^{b}$ & & \\
\hline & 80 & $1.04 \times 10^{-08}\left( \pm 1.87 \times 10^{-09}\right)^{c}$ & & \\
\hline \multirow{3}{*}{$30^{\circ} \mathrm{C}, 1.0 \mathrm{~m} / \mathrm{s}$} & 40 & $2.64 \times 10^{-09}\left( \pm 2.88 \times 10^{-10}\right)^{\mathrm{a}}$ & \multirow{3}{*}{26.5} & \multirow{3}{*}{0.9985} \\
\hline & 60 & $5.24 \times 10^{-09}\left( \pm 1.90 \times 10^{-10}\right)^{\mathrm{b}}$ & & \\
\hline & 80 & $8.34 \times 10^{-09}\left( \pm 1.51 \times 10^{-09}\right)^{\mathrm{c}}$ & & \\
\hline
\end{tabular}

${ }^{\mathrm{x}}$ Values are averages \pm standard deviation of three samples measured in each experiment repeated three times. The values with the same lowercase letter in the column for each dehydration condition are not significantly different $(P<0.05)$.

produced the lowest value of $a_{w}$ and the highest value of splitting in the instant whole beans. The First Order model gave the best fit for the rehydration kinetics, with no significant differences $(P>0.05)$ between the observed and predicted equilibrium moisture contents of the instant whole beans. Therefore, an air temperature of $30^{\circ} \mathrm{C}$ and $0.5 \mathrm{~m} / \mathrm{s}$ air velocity can be recommended as the most appropriate dehydration conditions for the preparation of instant whole beans, because this produces desirable chemical, physical, and rehydration characteristics in the instant whole bean, including low levels of structural damage (splitting) and an appropriate value of $a_{w}$. 
TABLE 10: Values of water absorption capacity (WAC), dry matter holding capacity (DHC), and rehydration ability (RA) indexes at $80^{\circ} \mathrm{C}$ of rehydration of instant whole bean obtained at different conditions of dehydration ${ }^{\mathrm{x}}$.

\begin{tabular}{lcrr}
\hline $\begin{array}{l}\text { Dehydration } \\
\text { conditions }\end{array}$ & DHC & WAC & RA \\
\hline $25^{\circ} \mathrm{C}, 0.5 \mathrm{~m} / \mathrm{s}$ & $1.00 \pm 0.01^{\mathrm{a}}$ & $0.87 \pm 0.01^{\mathrm{ab}}$ & $0.87 \pm 0.01^{\mathrm{ab}}$ \\
$25^{\circ} \mathrm{C}, 1.0 \mathrm{~m} / \mathrm{s}$ & $1.00 \pm 0.01^{\mathrm{a}}$ & $0.84 \pm 0.02^{\mathrm{a}}$ & $0.84 \pm 0.02^{\mathrm{a}}$ \\
$30^{\circ} \mathrm{C}, 0.5 \mathrm{~m} / \mathrm{s}$ & $1.00 \pm 0.01^{\mathrm{a}}$ & $0.89 \pm 0.01^{\mathrm{b}}$ & $0.89 \pm 0.01^{\mathrm{b}}$ \\
$30^{\circ} \mathrm{C}, 1.0 \mathrm{~m} / \mathrm{s}$ & $1.00 \pm 0.01^{\mathrm{a}}$ & $0.88 \pm 0.02^{\mathrm{b}}$ & $0.88 \pm 0.02^{\mathrm{b}}$ \\
\hline
\end{tabular}

${ }^{\mathrm{x}}$ Values are averages \pm standard deviation of three samples measured in each experiment repeated three times. Mean values within the same column followed by the same superscript lowercase letter are not significantly different $(P<0.05)$.
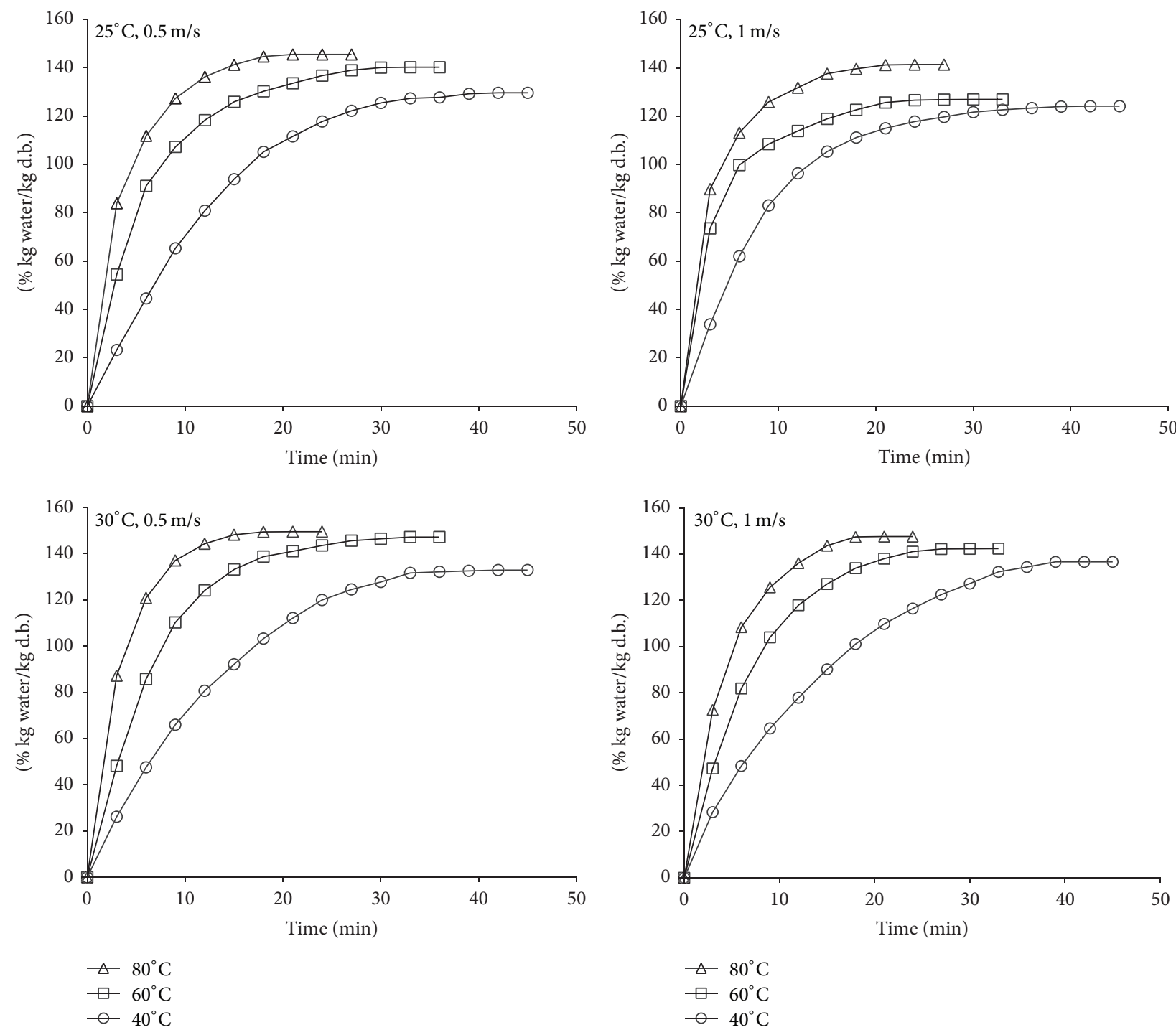

FIGURE 2: Rehydration kinetics of instant whole bean obtained at different conditions of dehydration and rehydration temperatures. 


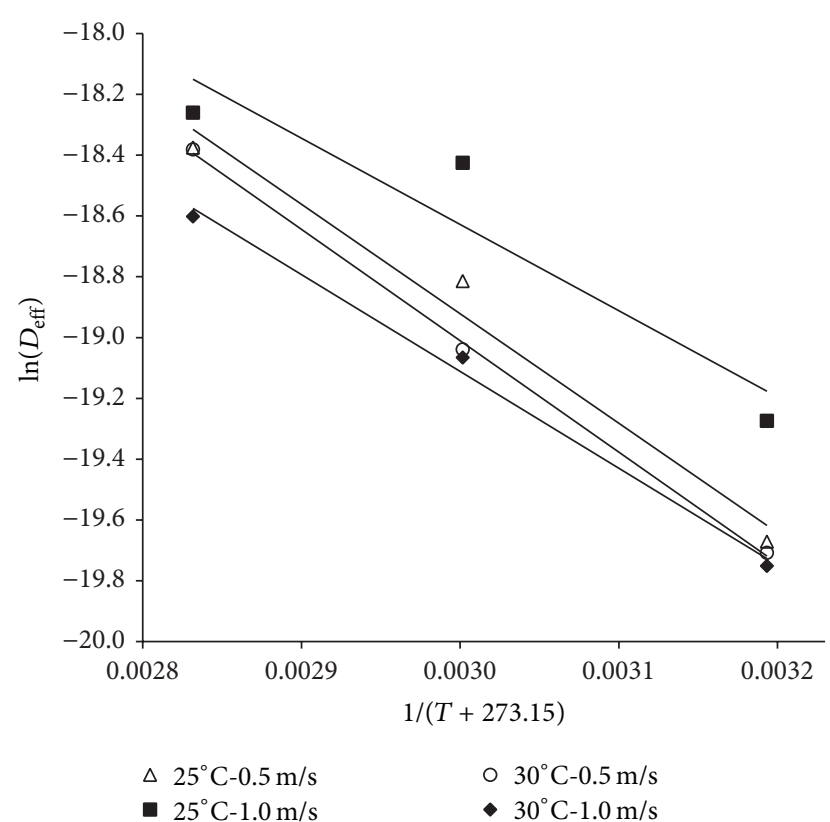

FIGURE 3: Variation of the diffusion coefficient of instant whole bean obtained at different conditions of dehydration and rehydration temperatures.

\section{Conflict of Interests}

The authors declare that there is no conflict of interests regarding the publication of this paper.

\section{Acknowledgment}

The authors wish to thank Promep-SEP, Mexico, for providing funds to support this research through Grant 2649-UANCA-6.

\section{References}

[1] N. Zamindar, M. S. Baghekhandan, A. Nasirpour, and M. Sheikhzeinoddin, "Effect of line, soaking and cooking time on water absorption, texture and splitting of red kidney beans," Journal of Food Science and Technology, vol. 50, no. 1, pp. 108114, 2013.

[2] M. Plans, J. Simó, F. Casañas, J. Sabaté, and L. RodriguezSaona, "Characterization of common beans (Phaseolus vulgaris L.) by infrared spectroscopy: comparison of MIR, FT-NIR and dispersive NIR using portable and benchtop instruments," Food Research International, vol. 54, no. 2, pp. 1643-1651, 2013.

[3] L. Silva-Cristobal, P. Osorio-Díaz, J. Tovar, and L. A. BelloPérez, "Chemical composition, carbohydrate digestibility, and antioxidant capacity of cooked black bean, chickpea, and lentil Mexican varieties," Ciencia y Tecnologia Alimentaria, vol. 8, no. 1, pp. 7-14, 2010.

[4] M. Pirhayati, N. Soltanizadeh, and M. Kadivar, "Chemical and microstructural evaluation of 'hard-to-cook' phenomenon in legumes (pinto bean and small-type lentil)," International Journal of Food Science and Technology, vol. 46, no. 9, pp. 18841890, 2011.
[5] S. Siah, J. A. Wood, S. Agboola, I. Konczak, and C. L. Blanchard, "Effects of soaking, boiling and autoclaving on the phenolic contents and antioxidant activities of faba beans (Vicia faba l.) differing in seed coat colours," Food Chemistry, vol. 142, pp. 461468, 2014.

[6] A. H. Martínez-Preciado, Y. Estrada-Girón, A. GonzálezÁlvarez, V. V. A. Fernández, E. R. Macías, and J. F. A. Soltero, "Physicochemical, morphological and rheological properties of canned bean pastes 'negro Queretaro' variety (Phaseolus vulgaris L.)," Journal of Food Science and Technology, vol. 51, no. 9, pp. 1795-1805, 2014.

[7] D. Güzel and S. Sayar, "Effect of cooking methods on selected physicochemical and nutritional properties of barlotto bean, chickpea, faba bean, and white kidney bean," Journal of Food Science and Technology, vol. 49, no. 1, pp. 89-95, 2012.

[8] FAO (Food and Agriculture Organization of the United Nations), FAOSTAT, http://faostat.fao.org/.

[9] D. A. L. Vital, E. G. de Mejía, V. P. Dia, and G. Loarca-Piña, "Peptides in common bean fractions inhibit human colorectal cancer cells," Food Chemistry, vol. 157, pp. 347-355, 2014.

[10] Dirección General de Industrias Básicas, Análisis de la Cadena de Valor del Frijol, Secretaría de Economía, Mexico City, Mexico, 2012.

[11] B. D. S. Siqueira, R. P. Vianello, K. F. Fernandes, and P. Z. Bassinello, "Hardness of carioca beans (Phaseolus vulgaris L.) as affected by cooking methods," LWT-Food Science and Technology, vol. 54, no. 1, pp. 13-17, 2013.

[12] M. Siddiq, R. Ravi, J. B. Harte, and K. D. Dolan, "Physical and functional characteristics of selected dry bean (Phaseolus vulgaris L.) flours," LWT-Food Science and Technology, vol. 43, no. 2, pp. 232-237, 2010.

[13] B. Guzmán-Méndez, M. E. Jaramillo-Flores, L. Chel-Guerrero, and D. Betancur-Ancona, "Comparison of physicochemical properties, antioxidant and metal-chelating activities of protein hydrolysates from Phaseolus lunatus and hard-to-cook Phaseolus vulgaris," International Journal of Food Science and Technology, vol. 49, no. 8, pp. 1859-1868, 2014.

[14] Z. Pan, G. G. Atungulu, L. Wei, and R. Haff, "Development of impact acoustic detection and density separations methods for production of high quality processed beans," Journal of Food Engineering, vol. 97, no. 3, pp. 292-300, 2010.

[15] G. O. Ondier, T. J. Siebenmorgen, and A. Mauromoustakos, "Low-temperature, low-relative humidity drying of rough rice," Journal of Food Engineering, vol. 100, no. 3, pp. 545-550, 2010.

[16] J. A. Ulloa, C. R. Bonilla-Sánchez, M. A. Ortíz-Jiménezc, P. Rosas-Ulloa, J. C. Ramírez-Ramírez, and B. E. Ulloa-Rangel, "Rehydration properties of precooked whole beans (Phaseolus vulgaris) dehydrated at room temperature," CyTA-Journal of Food, vol. 11, no. 1, pp. 94-99, 2013.

[17] G. R. Rodríguez-Licea, J. A. García-Salazar, S. RebollarRebollar, and A. C. Cruz-Contreras, "Preferencias del consumidor de frijol (Phaseolus vulgaris L.) en México: factores y características que influyen en la decisión de compra diferenciada por tipo y variedad," Paradigma Económico, vol. 2, no. 1, pp. 121145,2010

[18] K. G. Kaptso, Y. N. Njintang, A. E. Komnek, J. Hounhouigan, J. Scher, and C. M. F. Mbofung, "Physical properties and rehydration kinetics of two varieties of cowpea (Vigna unguiculata) and bambara groundnuts (Voandzeia subterranea) seeds," Journal of Food Engineering, vol. 86, no. 1, pp. 91-99, 2008.

[19] S. Cox, S. Gupta, and N. Abu-Ghannam, "Effect of different rehydration temperatures on the moisture, content of phenolic 
compounds, antioxidant capacity and textural properties of edible Irish brown seaweed," LWT-Food Science and Technology, vol. 47, no. 2, pp. 300-307, 2012.

[20] A. Midilli, H. Kucuk, and Z. Yapar, "A new model for singlelayer drying," Drying Technology, vol. 20, no. 7, pp. 1503-1513, 2002.

[21] A. Vega-Gálvez, M. Miranda, L. P. Díaz, L. Lopez, K. Rodriguez, and K. Di Scala, "Effective moisture diffusivity determination and mathematical modelling of the drying curves of the olivewaste cake," Bioresource Technology, vol. 101, no. 19, pp. 72657270, 2010.

[22] I. L. Pardeshi, S. Arora, and P. A. Borker, "Thin-layer drying of green peas and selection of a suitable thin-layer drying model," Drying Technology, vol. 27, no. 2, pp. 288-295, 2009.

[23] A. L. Oliveira, B. G. Colnaghi, E. Z. D. Silva, I. R. Gouvêa, R. L. Vieira, and P. E. D. Augusto, "Modelling the effect of temperature on the hydration kinetic of adzuki beans (Vigna angularis)," Journal of Food Engineering, vol. 118, no. 4, pp. 417420, 2013.

[24] AOAC, Official Methods of Analysis, Association of Official Analytical Chemists, Arlington, Va, USA, 2000.

[25] B. Zhao and K. C. Chang, "Evaluation of effects of soaking and precooking conditions on the quality of precooked dehydrated pea, lentil and chickpea products," Journal of Food Processing and Preservation, vol. 32, no. 3, pp. 517-532, 2008.

[26] M. Markowski and M. Zielińska, "Kinetics of water absorption and soluble-solid loss of hot-air-dried carrots during rehydration," International Journal of Food Science and Technology, vol. 46, no. 6, pp. 1122-1128, 2011.

[27] S. Rafiee, M. Sharifi, A. Keyhani et al., "Modeling effective moisture diffusivity of orange slice (Thompson Cv.)," International Journal of Food Properties, vol. 13, no. 1, pp. 32-40, 2010.

[28] K. O. Falade and O. J. Solademi, "Modelling of air drying of fresh and blanched sweet potato slices," International Journal of Food Science and Technology, vol. 45, no. 2, pp. 278-288, 2010.

[29] A. Vega-Gálvez, K. Ah-Hen, M. Chacana et al., "Effect of temperature and air velocity on drying kinetics, antioxidant capacity, total phenolic content, colour, texture and microstructure of apple (var. Granny Smith) slices," Food Chemistry, vol. 132, no. 1, pp. 51-59, 2012.

[30] Q. Shi, Y. Zheng, and Y. Zhao, "Mathematical modeling on thin-layer heat pump drying of yacon (Smallanthus sonchifolius) slices," Energy Conversion and Management, vol. 71, no. 1, pp. 208-216, 2013.

[31] D. B. Jadhav, G. L. Visavale, N. Sutar, U. S. Annapure, and B. N. Thorat, "Studies on Solar cabinet drying of green peas (Pisum sativum)," Drying Technology, vol. 28, no. 5, pp. 600-607, 2010.

[32] G. E. De Almeida Costa, K. Da Silva Queiroz-Monici, S. M. Pissini Machado Reis, and A. C. De Oliveira, "Chemical composition, dietary fibre and resistant starch contents of raw and cooked pea, common bean, chickpea and lentil legumes," Food Chemistry, vol. 94, no. 3, pp. 327-330, 2006.

[33] N. Wang, D. W. Hatcher, R. T. Tyler, R. Toews, and E. J. Gawalko, "Effect of cooking on the composition of beans (Phaseolus vulgaris L.) and chickpeas (Cicer arietinum L.)," Food Research International, vol. 43, no. 2, pp. 589-594, 2010.

[34] A. Vega-Gálvez, E. Notte-Cuello, R. Lemus-Mondaca, L. Zura, and M. Miranda, "Mathematical modelling of mass transfer during rehydration process of Aloe vera (Aloe barbadensis Miller)," Food and Bioproducts Processing, vol. 87, no. 4, pp. 254260, 2009.
[35] A. Yildirim, M. D. Öner, and M. Bayram, "Modeling of water absorption of ultrasound applied chickpeas (Cicer arietinum L.) using Peleg's equation," Journal of Agricultural Science, vol. 16, no. 4, pp. 278-286, 2010.

[36] M. Ghafoor, N. N. Misra, K. Mahadevan, and B. K. Tiwari, "Ultrasound assisted hydration of navy beans (Phaseolus vulgaris)," Ultrasonics Sonochemistry, vol. 21, no. 1, pp. 409-414, 2014.

[37] A. Reyes, A. Mahn, and F. Vásquez, "Mushrooms dehydration in a hybrid-solar dryer, using a phase change material," Energy Conversion and Management, vol. 83, pp. 241-248, 2014.

[38] A. Yildirim, M. D. Öner, and M. Bayram, "Fitting Fick's model to analyze water diffusion into chickpeas during soaking with ultrasound treatment," Journal of Food Engineering, vol. 104, no. 1, pp. 134-142, 2011.

[39] I. Doymaz and Ö. Özdemir, "Effect of air temperature, slice thickness and pretreatment on drying and rehydration of tomato," International Journal of Food Science and Technology, vol. 49, no. 2, pp. 558-564, 2014.

[40] J. Khazaei and N. Mohammadi, "Effect of temperature on hydration kinetics of sesame seeds (Sesamum indicum L.)," Journal of Food Engineering, vol. 91, no. 4, pp. 542-552, 2009.

[41] V. Schoeninger, S. R. M. Coelho, D. Christ, and S. C. Sampaio, "Processing parameter optimization for obtaining dry beans with reduced cooking time," LWT-Food Science and Technology, vol. 56, no. 1, pp. 49-57, 2014.

[42] I. Doymaz, "Effect of citric acid and blanching pre-treatments on drying and rehydration of Amasya red apples," Food and Bioproducts Processing, vol. 88, no. 2-3, pp. 124-132, 2010.

[43] R. Moreira, F. Chenlo, L. Chaguri, and C. Fernandes, "Water absorption, texture, and color kinetics of air-dried chestnuts during rehydration," Journal of Food Engineering, vol. 86, no. 4, pp. 584-594, 2008.

[44] P. García-Pascual, N. Sanjuán, J. Bon, J. E. Carreres, and A. Mulet, "Rehydration process of Boletus edulis mushroom: characteristics and modelling," Journal of the Science of Food and Agriculture, vol. 85, no. 8, pp. 1397-1404, 2005.

[45] S. Maldonado, E. Arnau, and M. A. Bertuzzi, "Effect of temperature and pretreatment on water diffusion during rehydration of dehydrated mangoes," Journal of Food Engineering, vol. 96, no. 3, pp. 333-341, 2010. 

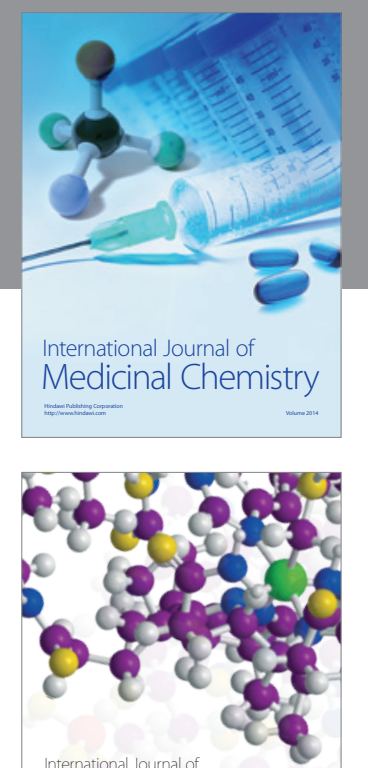

\section{Carbohydrate} Chemistry

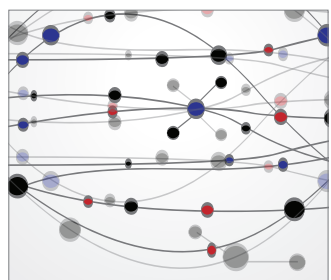

The Scientific World Journal
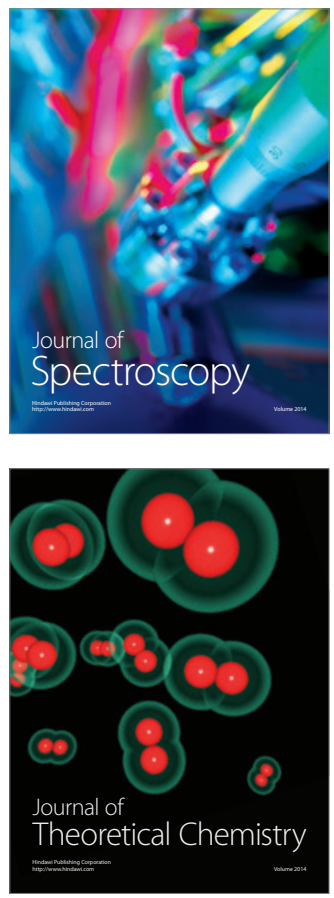
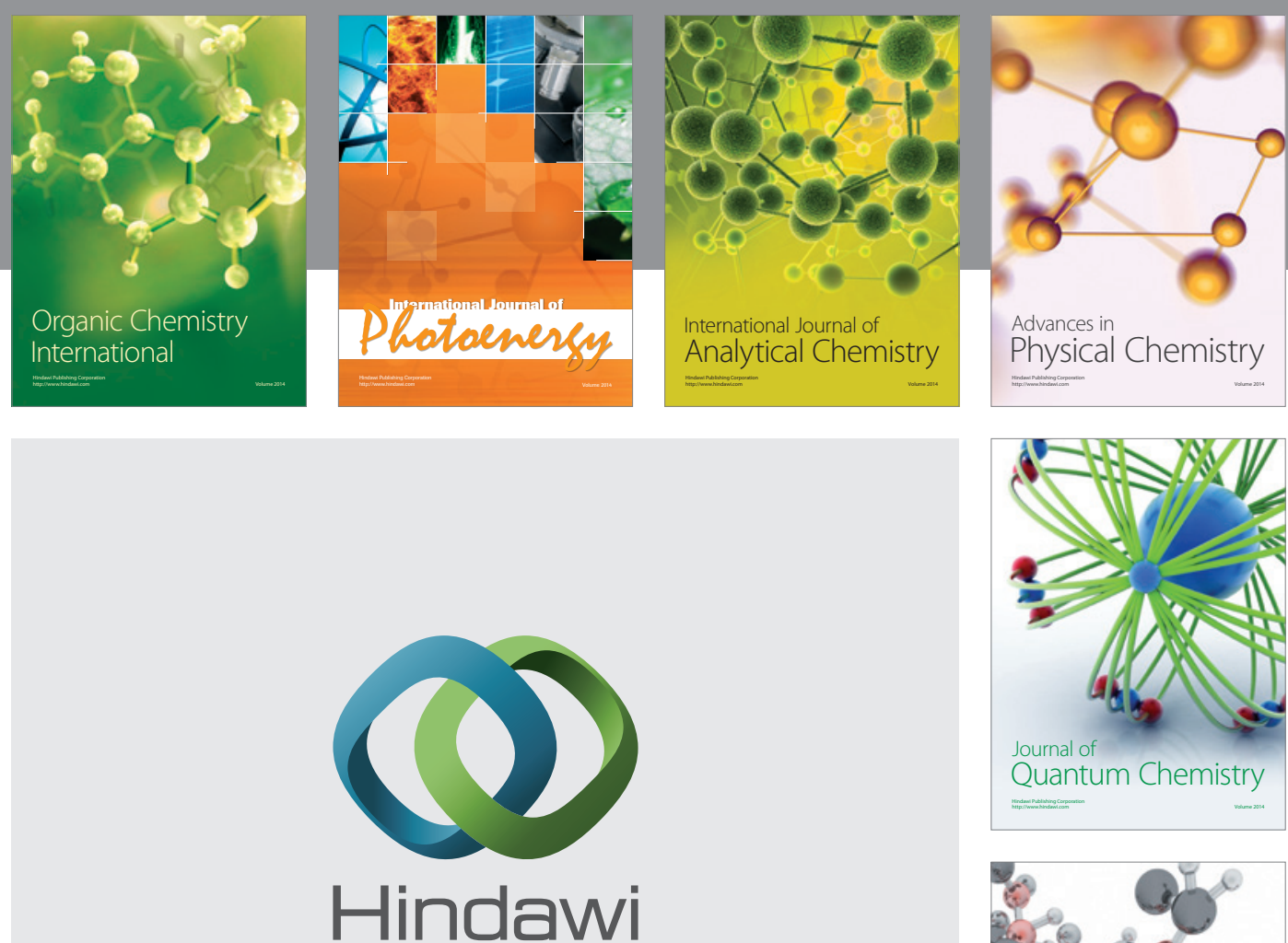

Submit your manuscripts at

http://www.hindawi.com

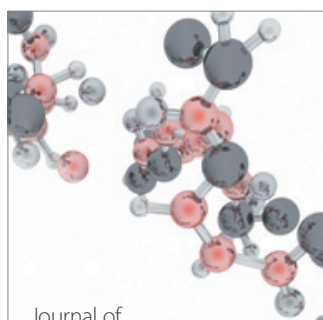

Analytical Methods

in Chemistry

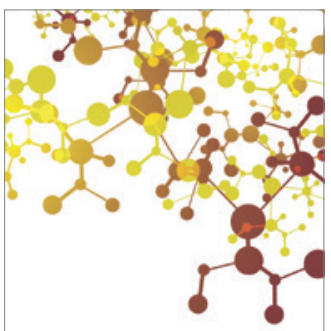

Journal of

Applied Chemistry

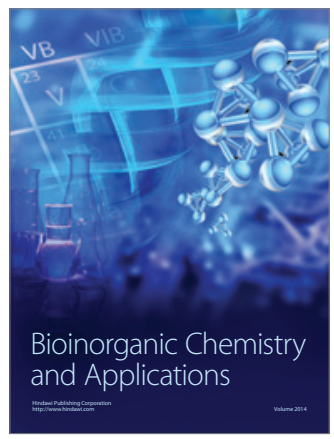

Inorganic Chemistry
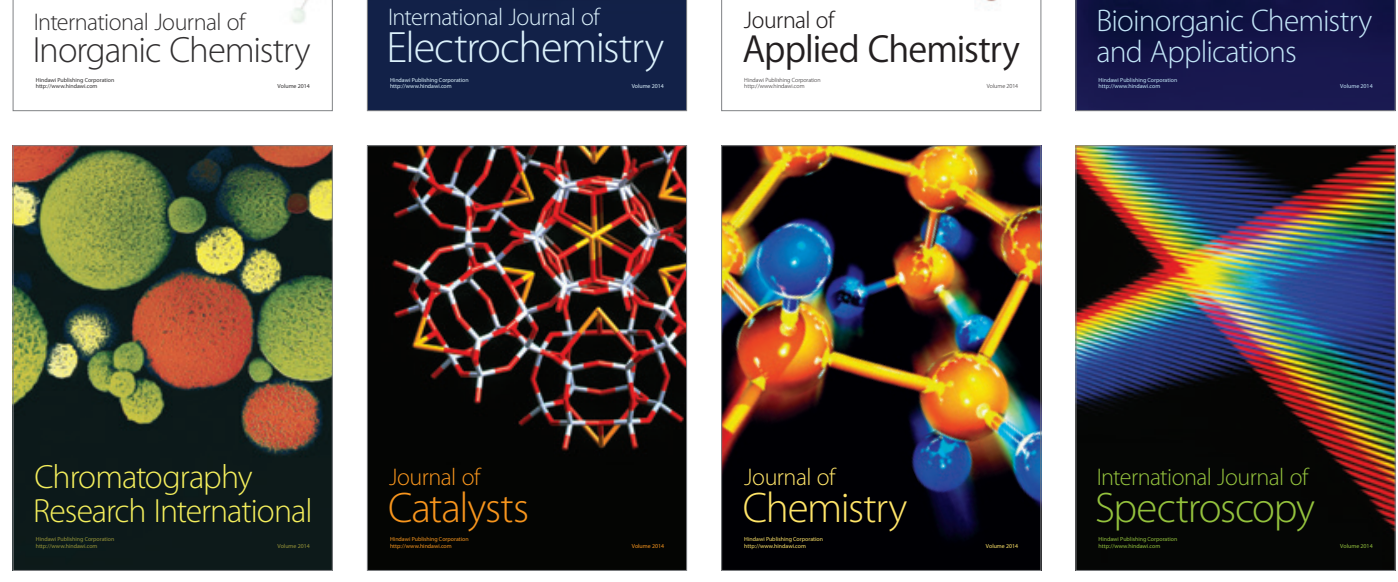